\title{
Correspondence
}

https://doi.org/10.11646/phytotaxa.343.1.10

\section{Massonia inaequalis (Asparagaceae, Scilloideae), a distinct new species from South Africa}

\author{
MARIO MARTÍNEZ-AZORÍN ${ }^{1 *}$, MICHAEL PINTER ${ }^{2}$, MANUEL B. CRESPO ${ }^{1}$, MARÍA ÁNGELES ALONSO \\ VARGAS $^{1} \&$ WOLFGANG WETSCHNIG ${ }^{2}$ \\ ${ }^{I} d C A R N$ (Depto. de Ciencias Ambientales y Recursos Naturales) \& CIBIO (Instituto Universitario de la Biodiversidad), Universidad de \\ Alicante, P. O. Box 99,E-03080 Alicante, Spain.e-mail: mmartinez@ua.es \\ ${ }^{2}$ Institute of Plant Sciences, NAWI Graz, Karl-Franzens-University Graz, Holteigasse 6, A-8010, Graz, Austria \\ *author for correspondence
}

Asparagaceae subfamily Scilloideae, tribe Hyacintheae is alternatively regarded as Hyacinthaceae subfam. Hyacinthoideae, a treatment we favour. Additional information on generic circumscriptions in Hyacinthoideae can be found in Martínez-Azorín et al. (2013, 2014a, 2014b), Pinter et al. (2013) and Wetschnig et al. (2014).

The genus Massonia Houttuyn (1780: 424) belongs to tribe Massonieae of Hyacinthoideae (Speta 1998a, 1998b, Wetschnig et al. 2002, Pfosser et al. 2003, Manning et al. 2004) and is confined to South Africa and southwestern Namibia. Our studies in Massonia reveal that the taxonomy of the genus, as presented in recent revisions, is not satisfactory and several species concepts have been overlooked and misunderstood (Martínez-Azorín et al. 2013, 2014a, 2014b, 2015a, 2015b, 2017, 2018, Pinter et al. 2013, 2015, Wetschnig et al. 2012, 2014, 2016).

Within the framework of a taxonomic revision of Massonia, the study of herbarium vouchers in the main South African herbaria and natural populations, revealed the existence of some populations of Massonia growing in the surroundings of Elands Bay (Western Cape Province of South Africa), that represent an undescribed species based on a distinct combination of morphological features, especially regarding flower morphology which show permanently erect perigone segments at anthesis, being unique in the genus. These plants were first collected by W.F. Barker in August 1966 in fruit near Elands Bay and after cultivating them at Kirstenbosch in the following 2 years, Barker deposited 4 herbarium vouchers including plants in flower and fruit, and also photographs of the plants. Barker left the plants unnamed in the original collection in fruit in August 1966 but later, after seeing flowers in cultivation, she named the plants as "Polyxena? Massonia?" evidencing her doubts on their generic placement in June 1968. Finally she recognized it as a new species as "Massonia? inaequalis Barker ms." in May 1969. However, this name has never been published and this species has remained unnamed ever since. Therefore, a formal description for this species is here presented, accepting the Barker's suggested name and authority, and including complete data on morphology, habitat, biology and distribution.

\section{Materials and Methods}

Detailed morphological studies of Massonia were undertaken on natural populations, cultivated specimens and herbarium vouchers, as elaborated upon in Martínez-Azorín et al. (2007, 2009). Herbarium specimens from the herbaria ABH, B, BLFU, BM, BOL, E, G, GZU, GRA, HAL, K, L, LINN, M, MO, NBG, NU, NY, P, PRE, S, TCD, UPS, W, WU, Z, ZSS and ZT (acronyms according to Thiers 2017) were studied. Author names of the cited taxa follow IPNI (2018). Orthography of geographical names and grid-number system follows Leistner \& Morris (1976).

\section{Description of the new species}

Massonia inaequalis W.F.Barker ex Mart.-Azorín, M.Pinter, M.B.Crespo, M.A.Alonso \& Wetschnig sp. nov.

Species notabilis combinatione propria characterum ab ceteris speciebus Massoniae bene distincta. Tunicae interiorae bulbi rubrescentes, membranaceae. Segmenta perigonii 9-10 × 2-2.5 mm, integerrima, albicantia, semper erecta, ad stamina occultantia. Staminum filamenta inaequalia, tria exteriora (5-7 mm long.) quam tria interiora (3-4 mm long.) subduplo longiora. Antherae caeruleae polline subconcoloro. Ovarium oblongum, 2.5-3.5 × 1.2-2 mm, viridulum, ad apicem leviter truncatum stylo bene distinctum.

Type:-SOUTH AFRICA. Western Cape. Clanwilliam (3218): Piketberg C.P., Elands Bay, on hill near school (-AD), 3 June 1968 (in flower ex hort), W.F.Barker 10435 (holotype NBG88401!). 


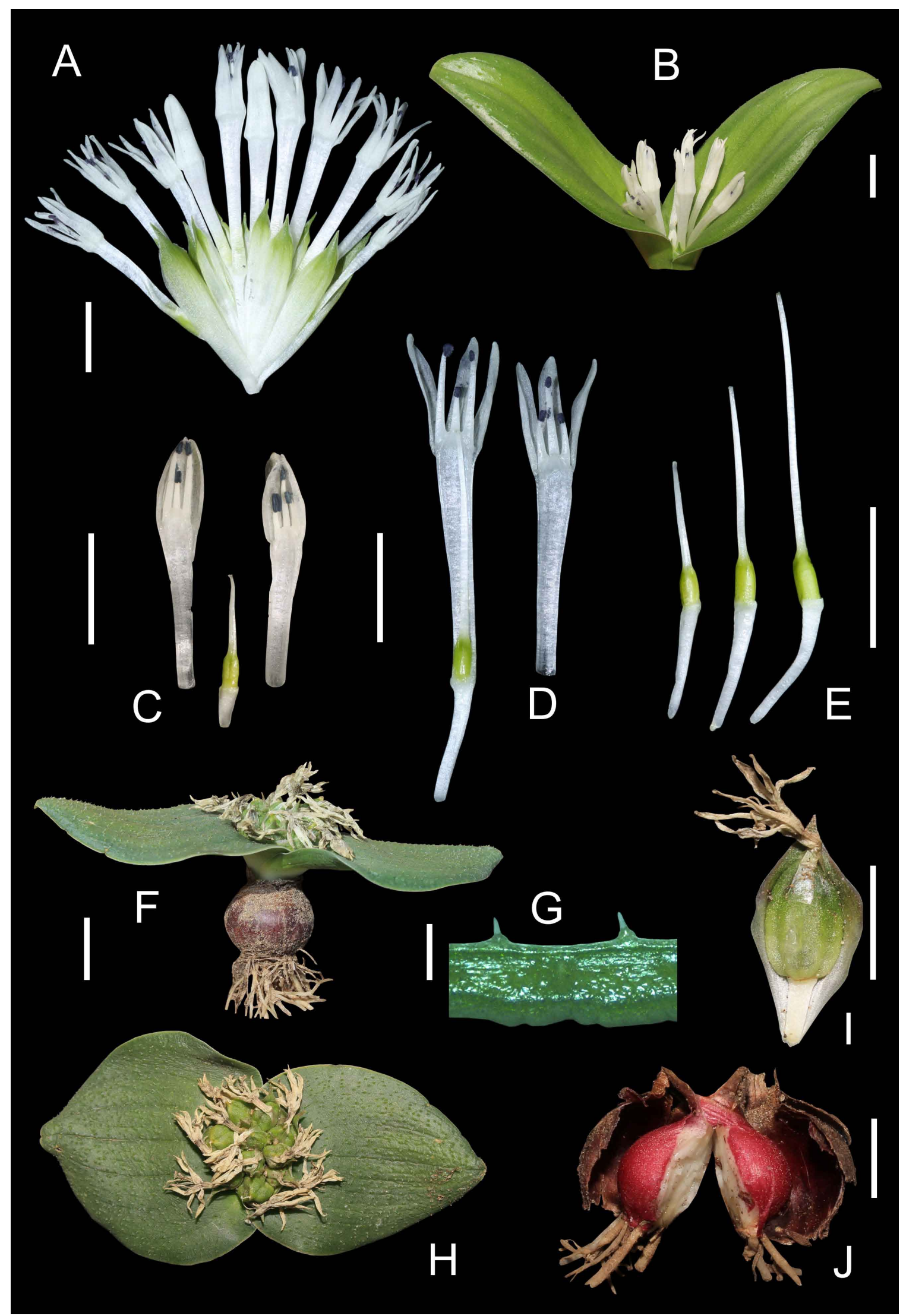

FIGURE 1. Massonia inaequalis W.F.Barker ex Mart.-Azorín et al. from Elands Bay, Western Cape province of South Africa (corresponding to MMA1726, A-E, G from plants in cultivation and F, H-J from wild plants). A. Inflorescence, lateral view; B. Plant in flower, lateral view; C. Dissected flower in bud, lateral view; D. Dissected flower at anthesis, lateral view; E. Gynoecia, from bud to fully developed flower, lateral views; F. Plant in fruit, lateral view; G. Transversal section of leaf showing emergences with trichomes; H. Plant in fruit, apical view; I. Unripe capsule with bract and withered perigone, lateral view; J. Dissected bulb with dark-brown leathery outer tunics and reddish, membranous inner tunics. Scale bars A-H, I-J: $1 \mathrm{~cm}$; G: $0.5 \mathrm{~mm}$. 
Deciduous geophyte. Bulb ovoid to subglobose, 1-1.7 $\times 1-2 \mathrm{~cm}$, slightly depressed in old plants, with white, fleshy bulb scales covered by membranous, reddish, inner tunics, and dark reddish-brown coriaceous outer tunics. Leaves 2, synanthous, opposite, appressed to the ground, ovoid to lanceolate, longitudinally striate, limb 2-8 $\times 1-4 \mathrm{~cm}$, with narrow, membranous, minutely papillose margins; adaxial side green, with 10-50 isodiametric emergences per $\mathrm{cm}^{2}$, up to $2 \mathrm{~mm}$ in length, with narrowly conical trichomes, $0.2-1 \mathrm{~mm}$ long; abaxial side smooth, green; petiole 5-10 $\mathrm{mm}$ long. Inflorescence dense, subcapitate raceme, ca. $1 \mathrm{~cm}$ long, with up to 20 flowers, shortly overtopping ground level. Bracts narrowly obovate-lanceolate, attenuate at the apex, 14-28 $\times 4-9 \mathrm{~mm}$, green in the upper half with white entire membranous margins and base, glabrous, minutely papillate on margins. Pedicels at anthesis $6-9 \mathrm{~mm}$ long. Flowers pentacyclic, trimerous. Perigone long and narrowly tubular, slightly widening at the end of the tube formed by 6 white tepals; free segments of tepals $9-10 \times 2-2.5 \mathrm{~mm}$, entire, white, straight and erect from bud to full anthesis; perigone-filaments tube 16-22 $\times 2-3 \mathrm{~mm}$, narrowly conical, widening in the upper portion, the ovary deeply included in the tube. Stamens 6. Filaments white, cylindrical, long-attenuate, unequal in size, outers much longer than inners, outers 5-7 mm long, inners 3-4 mm long, erect at anthesis, connate at the base for ca. $1 \mathrm{~mm}$ above the perigone segments; anthers oblong, dark blue, 1.2-1.6 $\times 0.4-0.6 \mathrm{~mm}$ when closed, dorsifixed, with blue pollen. Gynoecium tricarpelar, syncarpic. Ovary oblong, pale green, $2.5-3.5 \times 1.2-2 \mathrm{~mm}$, slightly truncate on top, clearly differentiated from the style. Style white, gradually tapering into the apex, erect, $12-17 \mathrm{~mm}$ long at anthesis. Capsule ovate-oblong in lateral view, trigonous with blunt edges in apical view, $8-11 \times 4-8 \mathrm{~mm}$. Seeds globose, black, $(1.1-) 1.3(-1.5) \times$ $(0.9-) 1.1(-1.4) \mathrm{mm}$, smooth.

Etymology:-The specific epithet (inaequalis) refers to the stamen filaments that are unequal in length, with the outer about twice as long as the inner ones. W.F. Barker in scheda named the new Massonia "Massonia? inaequalis Barker ms." in May 1969, a name we follow here.

Phenology:-Massonia inaequalis flowers between May and July in the wild and fruits appear from July to September.

Habitat:-Massonia inaequalis is found in crevices of exposed sandstone supporting arid FFs2 Graafwater Sandstone Fynbos vegetation and on shallow soil of arid strandveld covering slopes of coastal koppies. Climatically the region is characterised by winter rainfall peaking from May to August, with frequent occurrence of dense morning fog in winter; the mean annual precipitation of about $270 \mathrm{~mm}$ and frost is rare (Mucina \& Rutherford 2006).

Distribution:- The new species is known to us only from a few local populations in the surroundings of Elands Bay.

Taxonomic relationships:-Massonia inaequalis is unique in the genus showing permanently erect free segments of tepals enclosing the stamens that together with the reddish inner tunics of the bulb, leaves bearing emergences with narrowly conical trichomes, the unequal length of the stamen filaments, the blue anthers and pollen, and the ovary slightly truncate to the style allow easy recognition. Barker first doubted about its generic classification to Polyxena or Massonia, based on her notes in schedis in June 1968. However, the study of the flower morphology leaves no doubt about its inclusion in Massonia, as Barker finally concluded, a fact also supported by our phylogenetic analyses in Massonia (not shown), in which M. inaequalis is deeply nested in Massonia.

Additional material studied (paratypes):-SOUTH AFRICA. Western Cape. Clanwilliam (3218): Piketberg, Elands Bay, on hill near school (-AD), 16 August 1966 (fruiting), W.F.Baker 10435 (NBG88184!); ibidem, 3 June 1968 (photographs in flower in cultivation), W.F.Baker 10435 (NBG153624!); ibidem, 28 May 1969 (photographs in flower), W.F.Baker 10435 (NBG153623!); Clanwilliam (3218): Elands Bay, near deposits ca. $300 \mathrm{~m} \mathrm{~S}$ of large koppie on southern side slopes of river (-AD), $60 \mathrm{~m}$ elevation, 16 August 2017 (fruiting), M. Martinez-Azorín, M.B. Crespo, M.A. Alonso, M. Pinter MMA1726 (ABH!, GRA!); Clanwilliam (3218): Elands Bay, photo on iSpot 5 May 2013 in flower, Johan Potgieter (https://www.ispotnature.org/communities/southern-africa/view/observation/353093/ wildflowers288); Clanwilliam (3218): Elands Bay, photo on iSpot 22 August 2016 in fruit, Jean André Audissou (https://www.ispotnature.org/communities/southern-africa/view/observation/664265/bulb).

\section{Acknowledgements}

This work was partly supported by H2020 Research and Innovation Staff Exchange Programme of the European Commission, project 645636: 'Insect-plant relationships: insights into biodiversity and new applications' (FlyHigh). CapeNature of Western Cape Province provided permission to collect herbarium specimens (collecting permit number 0028-AAA008-00203). We acknowledge the help of all herbaria curators who kindly provided material and information. We also would like to thank all the numerous garden and plant enthusiasts who publish valuable information and 
images on plants on the internet and who contribute substantially to the increase of knowledge, and especially to Johan Potgieter and Jean André Audissou who published images and locality information of the new Massonia on the internet.

\section{References}

Houttuyn, M. (1780) Natuurlijke Historie of uitvoerige Beschryving der Dieren, Planten en Mineraalen, volgens het Samenstel van der Heer Linnaeus II, 12, Amsterdam, 558 pp.

IPNI (2018) The International Plant Names Index. Available from: http://www.ipni.org (accessed January 2018)

Leistner, O.A. \& Morris, J.W. (1976) Southern African Place Names. Annals of the Cape Provincial Museum 12: 1-565.

Manning, J.C., Goldblatt, P. \& Fay, M.F. (2004) A revised generic synopsis of Hyacinthaceae in Sub-Saharan Africa, based on molecular evidence, including new combinations and the new tribe Pseudoprospereae. Edinburgh Journal of Botany 60: 533-568.

Martínez-Azorín, M., Crespo, M.B. \& Juan, A. (2007) Taxonomic revision of Ornithogalum subg. Cathissa (Salisb.) Baker (Hyacinthaceae). Anales del Jardin Botánico de Madrid 64: 7-25.

https://doi.org/10.3989/ajbm.2007.v64.i1.47

Martínez-Azorín, M., Crespo, M.B. \& Juan, A. (2009) Taxonomic revision of Ornithogalum subg. Beryllis (Hyacinthaceae) in the Iberian Peninsula and the Balearic Islands. Belgian Journal of Botany 142: 140-162.

Martínez-Azorín, M., Pinter, M., Crespo, M.B., Pfosser, M. \& Wetschnig, W. (2013) Massonia mimetica (Hyacinthaceae, Hyacinthoideae), a new remarkable species from South Africa. Stapfia 99: 187-197.

Martínez-Azorín, M., Clark, V.R., Pinter, M., Dold, A.P., Crespo, M.B., Barker, N.P., Pfosser, M. \& Wetschnig, W. (2014a) Massonia dentata (Asparagaceae, Scilloideae), a new species from the Nuweveldberge, southern Great Escarpment, South Africa and typification of M. calvata. Phytotaxa 175: 201-215.

https://doi.org/10.11646/phytotaxa.175.4.2

Martínez-Azorín, M., Pinter, M., Deutsch, G., Brudermann, A., Dold, A.P., Crespo, M.B., Pfosser, M. \& Wetschnig, W. (2014b) Massonia amoena (Asparagaceae, Scilloideae), a striking new species from the Eastern Cape, South Africa. Phytotaxa 181: 121-137. https://doi.org/10.11646/phytotaxa.181.3.1

Martínez-Azorín, M., Dold, A.P., Pinter, M., Slade, J., Crespo, M.B., Milkuhn, G. \& Wetschnig, W. (2015a) Massonia obermeyerae (Asparagaceae, Scilloideae), a new species from South Africa. Phytotaxa 205: 39-50. https://doi.org/10.11646/phytotaxa.205.1.3

Martínez-Azorín, M., Pinter, M., Crespo, M.B., Slade, J., Deutsch, G. \& Wetschnig, W. (2015b) Clarification of Massonia echinata and some other frequently misunderstood Massonia species (Asparagaceae, Scilloideae), with the description of M. pseudoechinata and M. roggeveldensis. Phytotaxa 239: 101-129.

https://doi.org/10.11646/phytotaxa.239.2.1

Martínez-Azorín, M., Pinter, M., Crespo, M.B., Alonso Vargas, M.A. \& Wetschnig, W. (2017) Massonia gypsicola (Asparagaceae, Scilloideae), a new species from the Knersvlakte in South Africa. Phytotaxa 308: 144-150. https://doi.org/10.11646/phytotaxa.308.1.16

Martínez-Azorín, M., Pinter, M., Crespo, M.B., Alonso Vargas, M.A. \& Wetschnig, W. (2018) Massonia visseriae (Asparagaceae, Scilloideae): rediscovery of a neglected species of Neobakeria and its transfer to Massonia. Phytotaxa 334: 70-74. https://doi.org/10.11646/phytotaxa.334.1.11

Mucina, L. \& Rutherford, M.C. (Eds.) (2006) The vegetation of South Africa, Lesotho and Swaziland. South African National Biodiversity Institute, Pretoria, $807 \mathrm{pp}$.

Pfosser, M., Wetschnig, W., Ungar, S. \& Prenner, G. (2003) Phylogenetic relationships among genera of Massonieae (Hyacinthaceae) inferred from plastid DNA and seed morphology. Journal of Plant Research 116: 115-132.

Pinter, M., Brudermann, A., Crespo, M.B., Deutsch, G., Martínez-Azorín, M., Müller-Doblies, U., Müller-Doblies, D., Pfosser, M. \& Wetschnig, W. (2013) Massonia citrina (Hyacinthaceae, Hyacinthoideae) - a new species from the Western Cape Province (South Africa). Phytotaxa 112: 50-56. https://doi.org/10.11646/phytotaxa.112.2.3

Pinter, M., Martínez-Azorín, M., Crespo, M.B. \& Wetschnig, W. (2015) Massonia bakeriana (Asparagaceae, Scilloideae), a new pustulate species from the Northern Cape Province (South Africa). Phytotaxa 222: 51-60.

https://doi.org/10.11646/phytotaxa.222.1.5

Speta, F. (1998a) Hyacinthaceae. In: Kubitzki, K. (Ed.) The families and genera of vascular plants 3. Springer, Berlin, pp. $261-285$. https://doi.org/10.1007/978-3-662-03533-7_35

Speta, F. (1998b) Systematische Analyse der Gattung Scilla L. s.l. (Hyacinthaceae). Phyton (Horn) 38: 1-141. 
Thiers, B. (2018) Index Herbariorum: A global directory of public herbaria and associated staff. New York Botanical Garden's Virtual Herbarium. Available from: http://sweetgum.nybg.org/ih/ (accessed January 2018)

Wetschnig, W., Pfosser, M. \& Prenner, G. (2002) Zur Samenmorphologie der Massonieae Baker 1871 (Hyacinthaceae) im Lichte phylogenetisch interpretierter molekularer Befunde. Stapfia 80: 349-379.

Wetschnig, W., Brudermann, A., Knirsch, W., Pinter, M. \& Pfosser, M. (2012) Massonia pustulata Jacq. 1791 and M. longipes Baker 1897 (Hyacinthaceae), two frequently misunderstood species - or how M. pustulata became depressed. Stapfia 97: $210-221$.

Wetschnig, W., Martínez-Azorín, M., Pinter, M., Brudermann, A., Deutsch, G., Crespo, M.B., Dold, A.P. \& Pfosser, M. (2014) Massonia saniensis (Asparagaceae, Scilloideae), a new species from Lesotho. Phytotaxa 173: 181-195. https://doi.org/10.11646/phytotaxa.173.3.1

Wetschnig, W., Martínez-Azorín, M. \& Pinter, M. (2016) Massonia thunbergiana (Hyacinthaceae-Hyacinthoideae), a new species from the cold heart of South Africa. Phyton (Horn) 56 (1): 111-119. 